\title{
Employee satisfaction analysis with human resource index
}

\author{
Luhur Prayogo $^{a^{*}}$, B. Adi Suryo Pranoto and Humiras Hardi Purba ${ }^{a}$
}

${ }^{a}$ Industrial Engineering Department, Mercubuana University, Indonesia

\begin{tabular}{l}
\hline C H R O N I C L E \\
\hline Article history: \\
Received: October 1, 2016 \\
Received in revised format: No- \\
vember 16, 2016 \\
Accepted: February 15, 2017 \\
Available online: \\
February 15, 2017 \\
\hline Keywords: \\
Satisfaction Index \\
HRI \\
Performance
\end{tabular}

\section{A B S T R A C T}

\begin{abstract}
The objective of this research is to investigate employee satisfaction in one of Indonesian business firms named $\mathrm{BM}^{*}$. The study also tries to identify different factors influencing on employee satisfaction in the firm and to give appropriate suggestion for performance improvement. Methodology of this research is based on a survey and a questionnaire based on Human Resource Index (HRI) with measure 15 is used for the assessment. The results show that employee satisfaction of $\mathrm{BM}^{*}$ was relatively high. However, some of the attributes show the HRI were low. The study gives some insight to improve the customer satisfaction.
\end{abstract}

C 2017 Growing Science Ltd. All rights reserved.

\section{Introduction}

Employee satisfaction is one of important elements in supporting productivity levels and also in increasing creativity of employees. Several studies show a strong correlation between the level of productivity and creativity of employees with the level of employee satisfaction. Employees who are satisfied tend to be more productive at work, and produce more innovative ideas. Instead, employees who are less satisfied or disappointed with the conditions of employment or office environment tend to be stagnated in the works and will be easily bored, tired. Therefore, all companies should undertake a process to see the level of satisfaction of their employees on a regular basis using a typical survey where the employees are asked to complete a questionnaire in Likert scale on various issues in the working environment. $\mathrm{BM}^{*}$ is a media consultant and advertising in Indonesia. The company is headquartered in Jakarta and it was established in 2001. Although still small scale, but BM* has been able to win several tenders in the field of marketing and brand research from both government and other private parties. BM* presently has about 66 people divided into five business units, namely marketing research, public relations, media specialist, media monitoring, and advertising.

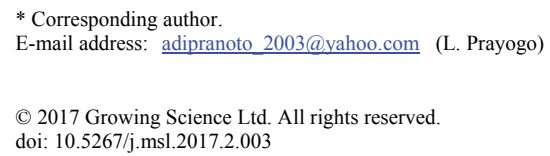




\section{Theoretical Background}

Job satisfaction is a pleasant emotional disposition and is associated with a person who loves his/her job. Employee job satisfaction must be created as much as possible in order to morale, dedication, passion, and increase the discipline of employees (McCormick \& Tiffin, 1979). This attitude is reflected by the morale, discipline, and job performance. Job satisfaction comfortable are in the job, off the job, and a combination of inside and outside of work. Job satisfaction in the organization is a job satisfaction enjoyed in the job by gaining praise the work, placement, treatment, equipment, and the atmosphere of a good working environment. Employees who prefer to enjoy job satisfaction in a job will prioritize work rather than remuneration even if the remuneration is important (Hasibuan, 2007).

Job satisfaction is a positive feelings about the work as a result of the evaluation of the job code (Robbins \& Judge, 2003). Similarly, Noe et al. (2007) defined job satisfaction as a pleasant feeling as a result of the perception that the work meets the values important work. Furthermore Kinicki and Kreitner (2005) define job satisfaction as an attitude or emotional response to various aspects of a person's job. This definition gives the meaning of that job satisfaction is not a single concept. Moreover one can be relatively satisfied with one aspect of his/her work and, at the same time, can be dissatisfied with one or various aspects. In a very similar views, Quick and Nelson (1997) found that job satisfaction is a positive emotional state and enjoyable as a result of the assessment of jobs or work experience person. High job satisfaction may result in a lower turnover rate (Mangkunagara, 2013). Job satisfaction relates to the attitude of employees toward work itself, work situation, cooperation between leaders and fellow leaders and fellow employees (Tiffin, 1979). Job satisfaction is a feeling or workers associated with his work, which was happy or not happy, as the results of the assessment of the individual concerned to work (Locke et al., 1998; Luthans, 1995). There are significant differences between work engagement and involvement of the organization (Saks, 2006). Engagement, such as trust, is a step forward from a commitment, which is evident in the interest of the organization to understand the involvement of all elements of the organization (Robinson et al., 2004). Herberg (1996) in his theory of Two Factors Theory says that job satisfaction and job dissatisfaction are two different things and the satisfaction and dissatisfaction with work that does not constitute a continuous variable. Dimensions of employee engagement is broken down into four dimensions: equity, achievement, camaraderie and leadership (Klein \& Ramsay, 2009).

Based on research conducted, Herberg split situation that affects a person's attitude toward his/her work into two groups: satisfiers and dissatisfiers group. Satisfiers group or motivators are factors or circumstances that is a source of job satisfaction which consists of achievement, recognition, work it self, responsibility and advancement. The presence of these factors can lead to job satisfaction, but the absence of these factors do not always lead to dissatisfaction (Herberg, 1996). While dissatisfiers groups are factors that proved to be a source of dissatisfaction which consists of company policy and administration, technical supervision, salary, interpersonal relations, working conditions, job security and status. Employees who are not satisfied with the job may interfere with the performance of the organization, which is a high turnover rate, absenteeism is high, inaction work, complaints, and even strikes (Andini, 2006). If a company has employees who have a high sense of belonging, it will make the employees feel at home working in these places and satisfaction will increase (Rachmawati, 2014). Improvement of the condition will reduce or eliminate dissatisfaction, but will not cause satisfaction because he is not a source of job satisfaction.

\section{Method}

This survey was conducted from September to October, 2016, at the headquarters of BM * in Jakarta, Indonesia. Methodology of this research is based on a survey and a questionnaire based on Human Resource Index (HRI) with measure 15 is used for the assessment. This method involves collecting primary data through questionnaires to employees in each group and the functional group management. 
The collection of data through questionnaires are conducted for all members of the population, 43 people.

In this survey, questionnaire design is mainly based on the concept of Human Resource Index (HRI) compiled by Frederick (1985). The dependent variable in this study is the level of employee satisfaction measured based on the relationship of the 15 pieces of independent variables selected. The independent variables are: System fee, Communication, Organizational Effectiveness, Cautions Against Employees, Goal Organization, Cooperation, Satisfaction Intrinsic, Organizational Structure \& Career Paths, Relationships Climate Organization / Work Environment, Participation Working Group, Cooperation Inter-group Work, Training and Development. Christen et al. (2006) provides a model of job satisfaction as presented in the figure below:

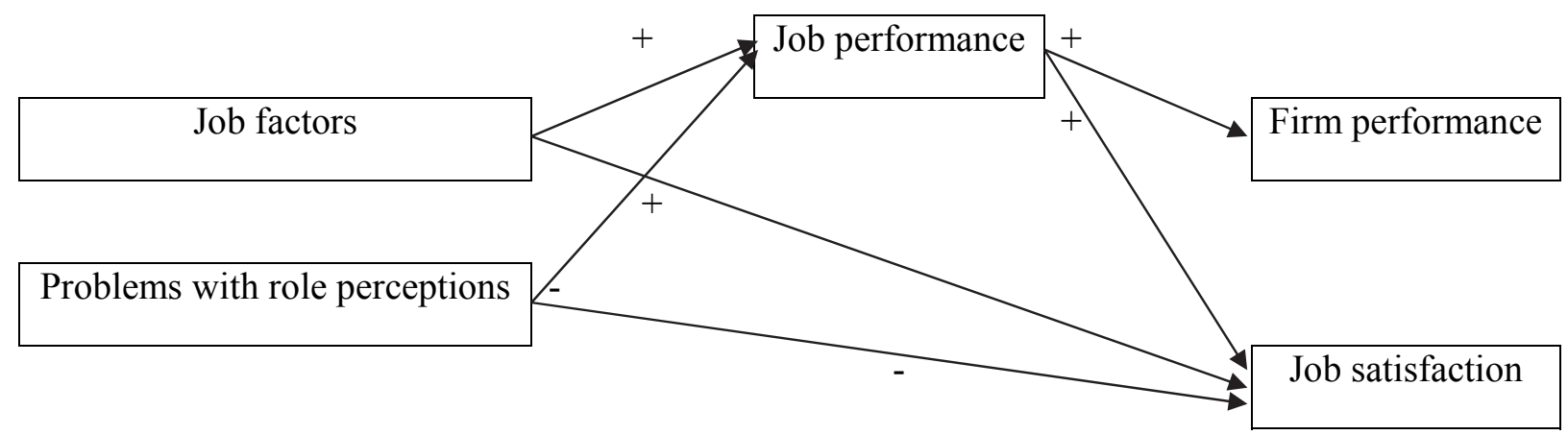

Fig. 1. Job Satisfaction Model

Source : http://www.ibimapublishing.net/journals/JSAR/2015/420802/420802.html

According to Aziri (2011), employee loyalty is one of the most significant factors for the concept of human resource managers. Employee loyalty as typically measured by questionnaire can lead to serious negative consequences when it is not in the high level. When employees are satisfied with their jobs and feel committed to the organization, they tend not to terminate their employment voluntarily (Tarigan \& Ariani, 2015). Low job satisfaction of individual causes the mind to leave the organization, which leads to an intention to find another job, thus causing the formation of an intention to leave the organization and finally actually moved in or out to leave the organization (Jaros et al., 1993). Continuance commitment is a structural phenomenon that occurs as a result of transactions of individuals and organizations (Yang, 2008). Measurement methods of each variable (independent variable) is by scoring with 15 questions given to respondents. The scoring result is processed further by quantitative analysis in terms of the descriptive statistics. Overall, the data processing results are then interpreted in accordance with the purpose of this survey. An assessment standard used in this survey uses a scale of Human Resource Index (HRI) which ranges from level 1 to 5. Level 1 shows the level of bad moral (demoralized), Level 2 means support (under-utilized), Level 3 is the condition average or standard (marginal), level 4 is a condition that effectively support the (effective) and level 5 refers to the level which resulted in commitments fully and effectively support the organization's efforts (fully committed and utilized).

\section{Results and Discussion}

\subsection{Respondents Data}

Respondents were divided based on employment status and job functions. Employment status consists of 32 permanent workers and 11 contract. While based functions consist of the core (core team of business) and support (See Table 1). 
Table 1

Respondents Data by Employment Status and Job Function

\begin{tabular}{cccc}
\hline & Status & \multicolumn{3}{c}{ Function } \\
\hline Permanent & Contract & Core & Support \\
\hline 32 & 11 & 28 & 15 \\
\hline
\end{tabular}

\subsection{Survey Results For All Employees}

Fig. 1 shows that in general the employees of $\mathrm{BM}^{*}$ had a positive view of the system. It also indicates that the level of employee satisfaction was also above average. The orange color represents the total value of HRI, HRI red indicates a value less than the average $(<3)$, while the blue color indicates HRI values equal to or more than the average $(\geq 3)$.

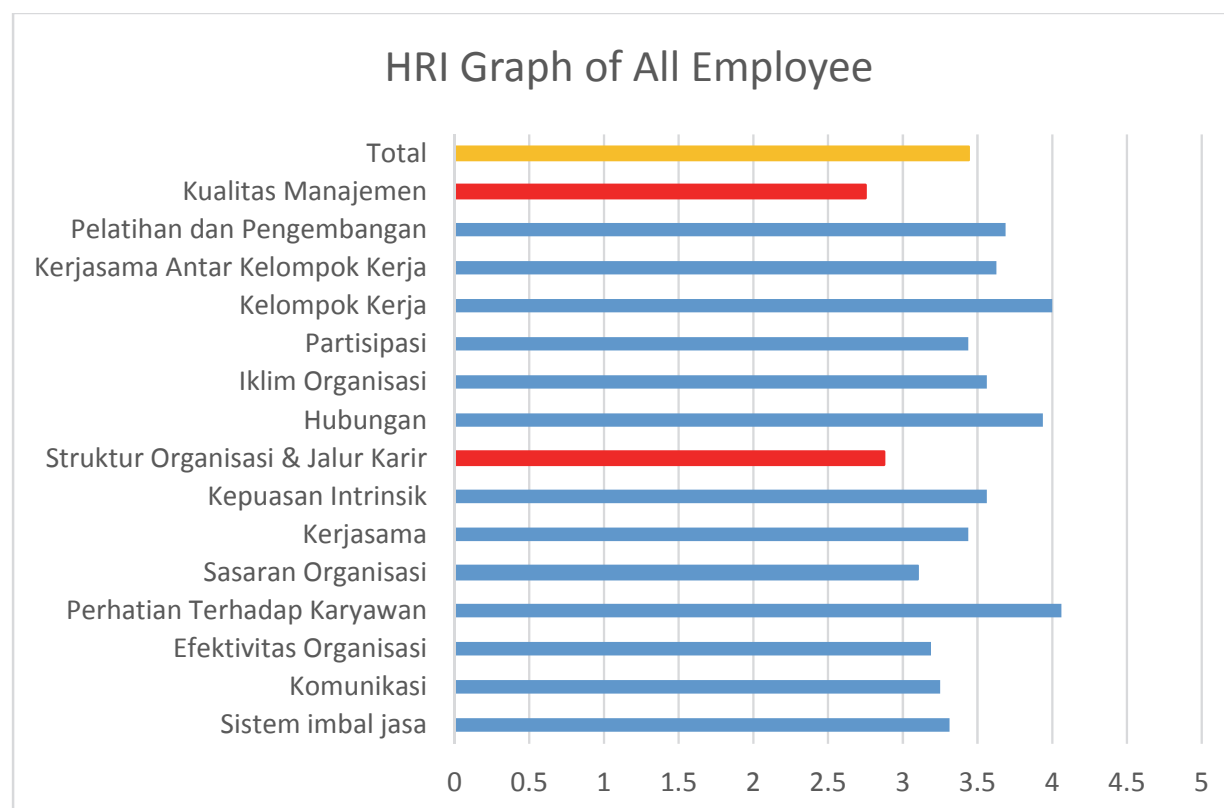

Fig. 2. HRI Graph of All Employees

The first factor, namely the Payments System Services, a factor that measures the overall compensation program, includes salary, allowances and benefits provided by the company. Employees give average ratings of 3.31 for this factor. This suggests that employees view the company has prevailed fairly in giving compensation. This is supported by the fact that the the wages were slightly above average given by information technology firms in Indonesia.

The second factor, Communications, measures the quality of the flow and distribution of information among all employees. Employees' responses to these factors indicate a positive result that is above average. This means that communication among employees $\mathrm{BM}^{*}$ were going quite well in terms of quality of information distribution.

The third factor is Organizational Effectiveness. This factor relates to the measurement of the level of employee confidence that the company was able to achieve its goals and objectives. BM* employees rated this factor above average. This illustrates that in general the quality of human resources was good and they could achieve the goals and objectives of the organization. Besides the above results also provide that information at every level managerial decisions were based on the data which was accurate, complete and ethical. 
The fourth factor is Caution Against Employees. This factor specifically measures the level of attention of the firm towards its employees. Rated 4.06, it is significantly above the average. Thus, the company is considered quite committed to the welfare and success of employees.

The fifth factor, Organizational Goals, measurs the perceptions of each employee to the company's goals and objectives. This section looks at whether the company has a clear goal, understood and can be proud of the employees, as well as whether they feel a part thereof. Assessment of these factors was found that the value of HRI was above average, amounting to 3.1, which indicates that the employee $\mathrm{BM}^{*}$ had sufficient understanding of the goals and objectives of the company and participated actively in the effort to achieve them.

The next factor, sixth, namely Cooperation, specifically measures the ability of employees to work together effectively towards a common goal. Figures ratings of 3.43 suggests that employees BM* classed as employees who are able to work together and support each other.

Seventh factor, Intrinsic Satisfaction, is a factor that measures the level of awards received by the employees based on their work. This includes a satisfactory work performance and progress in the development of self-competence. The assessment results were above-average and gives a positive picture that employees feel that their work was interesting and challenging. In addition, employees also feel to have the opportunity to become creative and express themselves well.

The eighth factor is the Organizational Structure and Career Paths. This factor relates to the rules of the organization, working procedures, organizational structures, levels of authority and responsibility, as well as career paths exist. Assessment of these factors indicates that the employees were not sufficiently informed about the structural changes that occur. Additionally, the career path, in general, employees had a poor perception.

The ninth factor is Relationships, measuring the quality of the relationship between the company's employees. This factor measures how each employee had relationships with his/her partners. The results achieved by $\mathrm{BM}^{*}$ for this factor is quite high, 3.93 and the positive result indicates that every employee felt glad to cooperate with co-workers.

Another factors are Organizational Climate and Environment. These factors collect employees' opinions on whether the work environment was comfort and adequate support to work well. In this case the employee assessment indicates that the existing facilities and adequate facilities and moral support were perceived positively. The other thing is about how employees behave toward conflict. Most of the respondents considered that the conflict was located in the limits of reasonableness and did not damage personal relationships or interfere with the achievement of work objectives.

Next factor, Participation factor, measures the level of each employee on the opportunity to be involved in the decision making process. This includes involvement in providing ideas, being well informed and involved in the decision-making process. This factor gets ratings that range at above average (3.43).

Factor Working Group, measures the ability of employees to work together with their immediate colleagues (team / group). The results obtained through the survey was very positive, which is in a state of effective (Level 4). Employees are generally described as having a high degree of cooperation and do not have the inhibiting factors.

Thirteenth factor is Cooperation Interagency Working Group, measures the ability of employees to work together with a separate working groups, both functionally and structurally. Survey shows that inter-group cooperation is at a pretty good rate. Employees generally positive attitudes towards others and working groups as well as over the implementation of cross-functional cooperation. 
Factors of Training and Development, measure the company's commitment to improve the quality of the employees and, at the same time, the ability of employers to provide training and guidance. BM* looks graded fairly high in this factor. It shows one of the strengths of the company.
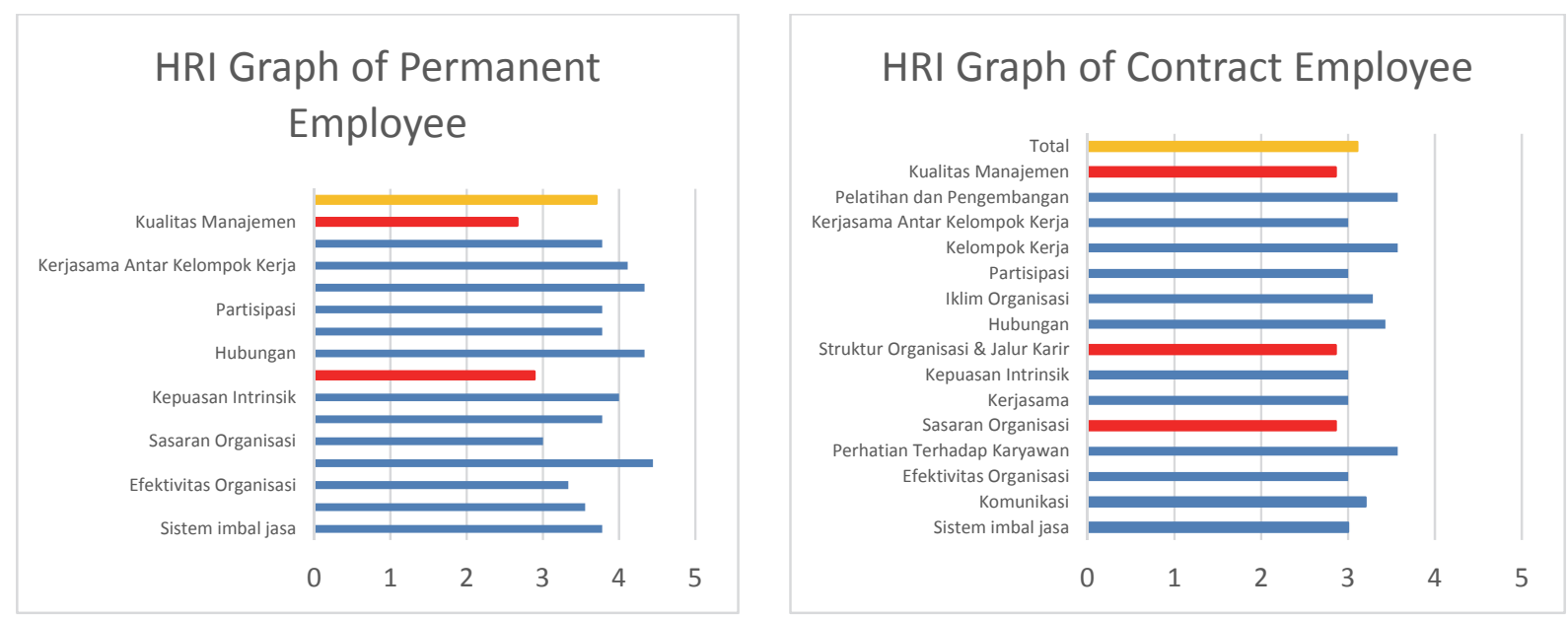

Fig. 3. HRI Graph both of Permanent and Contract Employees

The last factor, Quality Management, measures the level of appraisal of the quality of administration and archiving in the enterprise. For this factor, employees' appreciation was unfavorable, with a value of 2.75 (lowest). In general, employees saw the lacks of attention for archiving management and administration in the company.

\subsection{Survey Results Based on Employee Status}

Employee status at BM* is divided into two, permanent employees and contract employees. Permanent employees are employees who have worked more than six months in $\mathrm{BM}^{*}$ and are entitled to all the benefits provided by the company. While the contract employees are employees who work less than 6 months. In the three business units, BM* itself currently has 32 permanent staff and 11 contract employees. The survey results shown by Fig. 2 indicates that HRI values are still below the average for permanent employees in terms of the quality of management and organizational structures and career paths.

\subsection{Survey Results Based Functional Groups}

Functional groups in the three business units consists of BM* Researcher, Data Processing, Field (field team), Media Specialist, Media Monitoring, Editor, Digital Planner, Copywriter and Social Media Analytics. These three functions were incorporated in the Core Team. While other functional group consists of Marketing, Admin / Finance, HR, and IT and they are associated with members of the Support Team. In BM* alone currently has a core team of 28 people and a support team of 15 people.

The survey results indicated by Fig. 3 provides information that HRI values are still below the average for employees who are members of the core team while the value of HRI is below the average for the support team. 

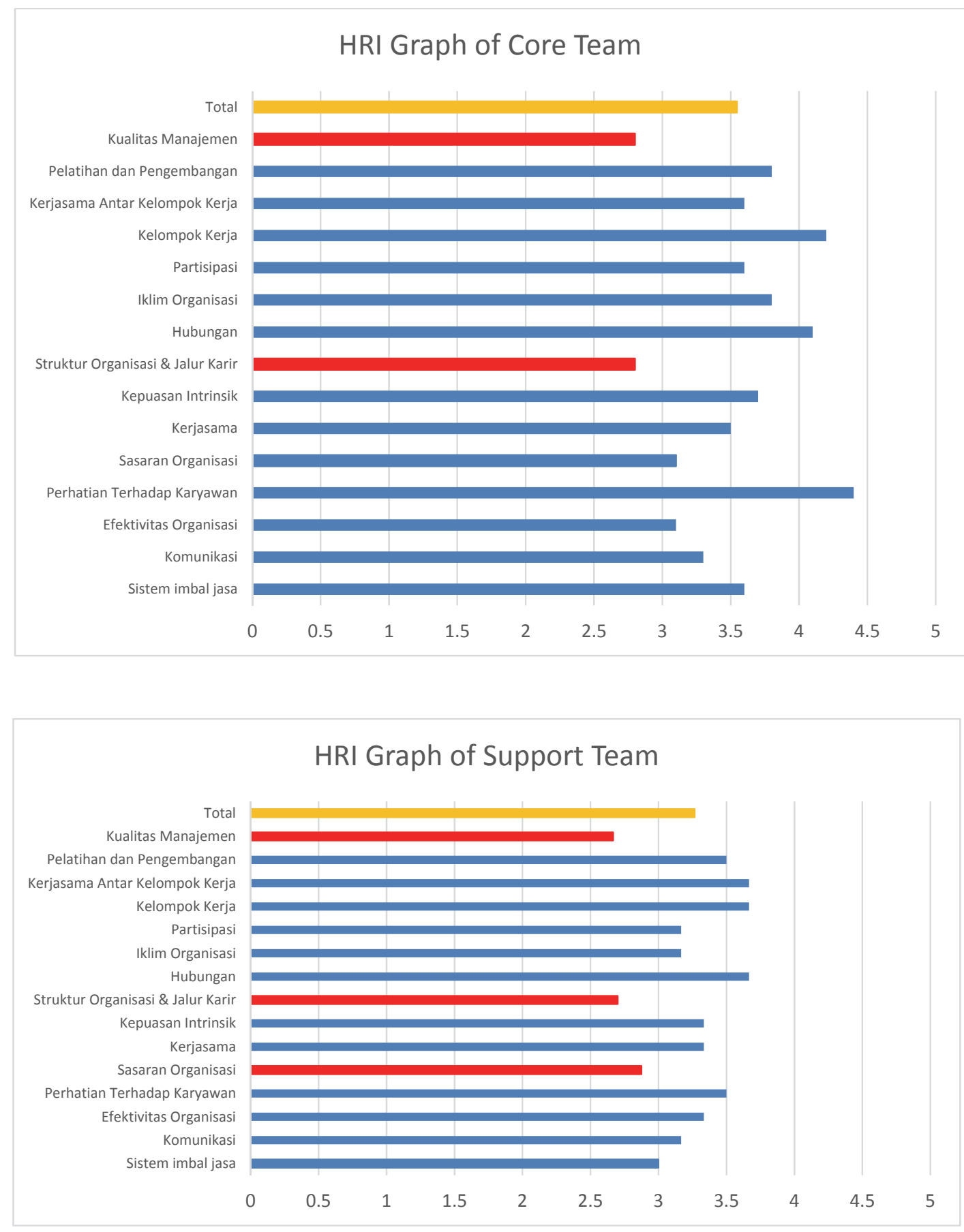

Fig. 4. HRI Graph of Core Team and Support Team

\section{Conclusion}

The results of employee satisfaction surveys using indicators HRI in $\mathrm{BM}^{*}$ in general are above the average or fairly desirable. But there were three issues on employee job dissatisfaction, such as quality management, organizational structure and career path and goals of the organization. The survey results also indicate quality issues of management, especially regarding archiving and administration maintained the lowest HRI. The employees believed that management of archives in BM* was still not well ordered. Many physical archives were stacked irregularly. The organizational structure and career path also show that the value of HRI was below average. This shows that the employees were not sufficiently 
informed about the structural changes that occur. Additionally, in terms of the career path, in general, employees had a poor perception. This is because the condition of the company was still in small scale. Other attributes that indicate HRI below average is the organization's objectives. The organization's objectives or the target company is only understood by a support team. Unlike the core team who were poorly informed about the goals of this organization. This can be corrected by organizing a sharing session with a support team of the objectives of the organization in the company.

\section{References}

Andini, R. (2006). Influence Analysis Satisfaction Salary, Job Satisfaction, Organizational Commitment Against Turnover Intention (A Case Study Roemani Muhammadiyah Hospital Semarang) (Doctoral dissertation, Program Pasca Sarjana Universitas Diponegoro).

Aziri, B. (2011). Job satisfaction: A literature review. Management research and practice, 3(4), 77-86.

Christen, M., Iyer, G., \& Soberman, D. (2006). Job satisfaction, job performance, and effort: A reexamination using agency theory. Journal of Marketing, 70(1), 137-150.

Herberg, F. (1966). Work and the nature of man. Cleveland: World Publishing Company.

Frederick, S. E. (1985). Human resource management: Concepts, cases and readings. Prentice-Hall Company.

Hasibuan, M. S. (2007). Human Resources Ranagement. $10^{\text {th }}$ ed. Jakarta. Alphabet Earth.

Jaros, S. J., Jermier, J. M., Koehler, J. W., \& Sincich, T. (1993). Effects of continuance, affective, and moral commitment on the withdrawal process: An evaluation of eight structural equation models. Academy of management Journal, 36(5), 951-995.

Klein, D. A \& Ramsay, C. (2009). Practical Guidance on Building A Solid Employee Engagemenl Survey.

Kreitner, R., \& Kinicki, A. (2005). Perilaku organisasi. Terjemahan, Salemba Empat, Jakarta.

Locke, E. A., Latham, G. P., \& Erez, M. (1988). The determinants of goal commitment. Academy of management review, 13(1), 23-39.

Luthans, F. (1995). Organisational behaviour.

Mangkunegara, P. Anwar. (2013). Human Resources Management.

McCormick, E. J., \& Tiffin, J. (1979). Industrial Psychology. Prentice-Hall, Inc., Englewood Cliffs, NJ $1965.682 \mathrm{p}$.

Noe, R. A., Hollenbeck, J. R., Gerhart, B., \& Wright, P. M. (2007). Fundamentals of human resource management. McGraw-Hill/Irwin.

Quick, D. L., \& Nelson, J. C. (1997). Organizational Behavior: Foundations, Realities, and Challenges.

Rachmawati, M. (2014). Employee engagement as a key to improving the performance of employees (International Journal Review). Jurnal Ilmiah Among Makarti, 6(12).

Robbins, S. P., \& Judge, T. A. (2003). Organizational Behavior. By Pearson Education. Inc., Upper Saddle River, New Jersey.

Robinson, D., Perryman, S., \& Hayday, S. (2004). The drivers of employee engagement: Institute of Employment Studies Report 408.

Saks, A. M. (2006). Antecedents and consequences of employee engagement. Journal of managerial psychology, 21(7), 600-619.

Tarigan, V., \& Ariani, D. W. (2015). Empirical study relations job satisfaction, organizational commitment, and turnover intention. Advances in Management and Applied Economics, 5(2), 21.

Yang, J. T. (2008). Effect of newcomer socialisation on organisational commitment, job satisfaction, and turnover intention in the hotel industry. The Service Industries Journal, 28(4), 429-443.

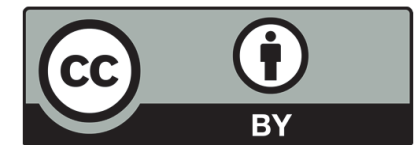

(C) 2017 by the authors; licensee Growing Science, Canada. This is an open access article distributed under the terms and conditions of the Creative Commons Attribution (CC-BY) license (http://creativecommons.org/licenses/by/4.0/). 